\title{
CONTRACTS OF ADHESION-SOME THOUGHTS ABOUT FREEDOM OF CONTRACT
}

\author{
Friedrich KessLer
}

With the development of a free enterprise system based on an unheard of division of labor, capitalistic society needed a highly elastic legal institution to safeguard the exchange of goods and services on the market. Common law lawyers, responding to this social need, transformed "contract" from the clumsy institution that it was in the sixteenth century into a tool of almost unlimited usefulness and pliability. Contract thus became the indispensable instrument of the enterpriser, enabling him to go about his affairs in a rational way. Rational behavior within the context of our culture is only possible if agreements will be respected. It requires that reasonable expectations created by promises receive the protection of the law or else we will suffer the fate of Montesquieu's Troglodytes, who perished because they did not fulfill their promises. This idea permeates our whole law of contracts, the doctrines dealing with their formation, performance, impossibility and damages.

Under a free enterprise system rationality of the law of contracts has still another aspect. ${ }^{1}$ To keep pace with the constant widening of the market the legal system has to place at the disposal of the members of the community an ever increasing number of typical business transactions and regulate their consequences. But the law cannot possibly anticipate the content of an infinite number of atypical transactions into which members of the community may need to enter. Society, therefore, has to give the parties freedom of contract; to accommodate the business community the ceremony necessary to vouch for the deliberate nature of a transaction has to be reduced to the absolute minimum. Furthermore, the rules of the common law of contract have to remain Jus dispositivum-to use the phrase of the Romans; that is, their application has to depend on the intention of the parties or on their neglect to rule otherwise. (If parties to a contract have failed to regulate its consequences in their own way, they will be supposed to have intended the consequences envisaged by the common law.) Beyond that the law cannot go. It has to delegate legislation to the contracting parties. As far as they are concerned, the law of contract has to be of their own making.

1. Max Weber, Rechtssoziologie, 3 (2) GRUndriss DER SozIALoEkonomir (2nd ed. 1925) 413 et seq. 
Thus freedom of contract does not commend itself for moral reasons only; it is also an eminently practical principle. It is the inevitable counterpart of a free enterprise system. ${ }^{1 \text { a }}$ As a result, our legal lore of contracts reflects a proud spirit of individualism and of laissez faire. This is particularly true for the axioms and rules dealing with the formation and interpretation of contracts, the genuineness and reality of consent. Contract-the language of the cases tells us-is a private affair and not a social institution. The judicial system, therefore, provides only for their interpretation, but the courts cannot make contracts for the parties. ${ }^{2}$ There is no contract without assent, but once the objective manifestations of assent are present, their author is bound. A person is supposed to know the contract that he makes. ${ }^{3}$ "A mere offer imposes no duty of action upon the offeree; there is no obligation to accept or reject or to take any notice of it." 4 If an offeror does not hear from the offeree about the offer, he is free to make inquiries or to withdraw his offer, but he cannot regard silence as an acceptance. Either party is supposed to look out for his own interests and his own protection. Oppressive bargains can be avoided by careful shopping around. Everyone has complete freedom of choice with regard to his partner in contract, and the privity-of-contract principle respects the exclusiveness of this choice. $\bar{\sigma}$ Since a contract is the result of the free bargaining of parties who are brought together by the play of the market and who meet each other on a footing of social and approximate economic equality, there is no danger that freedom of contract will be a threat to the social order as a whole. Influenced by this optimistic creed, courts are

1a. Pound, Liberty of Contract (1909) 18 YALE L. J. 454; Williston, Frecdom of Contract (1921) 6 CoRneLL L. Q. 365; Hamilton, Freedom of Contract, 3 ENCrC. Soc. Scr. 450.

2. Urian v. Scranton Life Insurance Company, 310 Pa. 144, 165 Atl. 21 (1933); Imperial Fire Insurance Company v. Coos County, 151 U. S. 452 (1894).

3. In the absence of fraud or misrepresentation parties who have put their contract in writing and signed it will not be heard to say that they have not read it or did not know, understand or assent to its contents provided the document is legible however small the print. L'Estrange v. F. Graucob Ltd., 2 K. B. 394 (1934). For American cases see 1 WiLliston, Contracts (rev. ed., 1936) \$90A.

4. Prosser, Delay in Acting on an Application for Instrrance (1935) 3 U. of CHI. L. REv. 39, 45.

5. Coast Fisheries Co. v. Iinen Thread Co., 269 Fed. 841 (D. Mass. 1921); Kaufman v. Sydeman, 251 Mass. 210, 146 N.E. 365 (1925). The evolution and gradual restriction of the privity of contract principle with the help of agency (undisclosed principal), third party beneficiary, assignment and tort doctrines expresses our awareness of the growing impersonality of the market and of the social function of contracts. We regard the undisclosed principal doctrine no longer as a wholly anomalous doctrine which ignores the fundamental notion of the common law "that a contract creates strictly personal obligations between the contracting parties." HUFFCUT, AGENCY (2d ed. 1921) 158; Ames, Undisclosed Principal-His Rights and Liabilities (1909) 18 YALE L. J. 443. The privity of contract doctrine no longer perfectly insulates the producer from direct liability to the ultimate consumer, as the food and dangerous instrumentality cases illustrate. 
extremely hesitant to declare contracts void as against public policy "because if there is one thing which more than another public policy requires it is that men of full age and competent understanding shall have the utmost liberty of contracting, and that their contracts when entered into freely and voluntarily shall be held sacred and shall be enforced by Courts of justice."

The development of large scale enterprise with its mass production and mass distribution made a new type of contract inevitable-the standardized mass contract. ${ }^{7}$ A standardized contract, once its contents have been formulated by a business firm, is used in every bargain dealing with the same product or service. The individuality of the parties which so frequently gave color to the old type contract has disappeared. The stereotyped contract of today reflects the impersonality of the market. It has reached its greatest perfection in the different types of contracts used on the various exchanges. Once the usefulness of these contracts was discovered and perfected in the transportation, insurance, and banking business, their use spread into all other fields of large scale enterprise, into international as well as national trade, and into labor relations. It is to be noted that uniformity of terms of contracts typically recurring in a business enterprise is an important factor in the exact ealculation of risks. Risks which are difficult to calculate can be excluded altogether. Unforseeable contingencies affecting performance, such as strikes, fire, and transportation difficulties ean be taken care of. 8 The standard clauses in insurance policies are the most striking illustrations of successful attempts on the part of business enterprises to select and control risks assumed under a contract. The insurance business probably deserves credit also for having first realized the full importance of the so-called " $\mathrm{ju}$ ridical risk", the danger that a court or jury may be swayed by "irrational factors" to decide against a powerful defendant. Ingenious clauses have been the result. ${ }^{9}$ Once their practical utility was proven, they were made use of in other lines of business. It is highly probable that the desire to avoid juridical risks has been a motivating factor in the widespread

6. Sir G. Jessel, M. R., in Printing and Numerical Registering Co. v. Sampson, L. R. $19 \mathrm{Eq} .462,465$ (1875).

7. Pausnitz, The Standardization of Comparercial Contracts in English and Continental. Law (1937) reviewed by Llewellyn (1939) 52 Harv. L. Rev. 700; Llewellyn, What Price Contract-An Essay in Perspective (1931) 40 Y $\mathrm{ALE}$ L. J. 704; Issacs, The Standardizing of Contracts (1917) 27 YALE L. J. 34 ; RAISER, Das Recht der Allgemeinen Geschaeftsbedingungen (1936).

8. For a far reaching clause in a sales contract see Hollis Bros. \& Co. Ltd. v. White Sea Timber Trust, Ltd., 3 All Eng. R. 895 (1936). Here the seller of timber from a port in the Arctic Circle open for navigation only about twentyone days stipulated "this contract is subject to sellers making necessary chartering arrangements for the expedition and sold subject to shipments any goods not shipped to be cancelled."

9. Patterson, Essentials of Insurance Law (1935) 282 et seq. 
use of warranty clauses in the machine industry limiting the common law remedies of the buyer to breach of an implied warranty of quality and particularly excluding his right to claim damages. ${ }^{10}$ The same is true for arbitration clauses in international trade. Standardized contracts have thus become an important means of excluding or controlling the "irrational factor" in litigation. In this respect they are a true reflection of the spirit of our time with its hostility to irrational factors in the judicial process, and they belong in the same category as codifications and restatements.

In so far as the reduction of costs of production and distribution thus achieved is reflected in reduced prices, society as a whole ultimately benefits from the use of standard contracts. And there can be no doubt that this has been the case to a considerable extent. The use of standard contracts has, however, another aspect which has become increasingly important. Standard contracts are typically used by enterprises with strong bargaining power. The weaker party, in need of the goods or services, is frequently not in a position to shop around for better terms, either because the author of the standard contract has a monopoly (natural or artificial) or because all competitors use the same clauses. His contractual intention is but a subjection more or less voluntary to terms dictated by the stronger party, terms whose consequences are often understood only in a vague way, if at all. Thus, standardized contracts are frequently contracts of adhesion; they are à prendre ou à laisser. ${ }^{11}$ Not infrequently the weaker party to a prospective contract even agrees in advance not to retract his offer while the offeree reserves for himself the power to accept or refuse $;^{\mathbf{1 2}}$ or he submits to terms or change of terms which will be communicated to him later. To be sure, the latter type of clauses regularly provide for a power to disaffirm, ${ }^{13}$ but as a practical matter they are acquiesced in frequently, thus becoming part of the "living law". Lastly, standardized contracts have also been used to control and regulate the distribution of goods from producer all the way down to the uttimate consumer. They have become one of the many devices to build up and strengthen industrial empires.

And yet the tremendous economic importance of contracts of ad-

10. For an effort of the legislature to protect the interests of the buyer of agricultural machinery see NORTH DAKOTA LAwS (1919) c. 238, construed in Palaniuk v. Allis Chalmers Mfg. Co., 57 N. D. 199, 220 N. W. 638 (1928).

11. The word "contract of adhesion" has been introduced into the legal vocabulary by Patterson, The Delivery of a Life Instirance Policy (1919) 33 Harv. L. REv. 198, 222.

12. Cole, McIntyre, Norfleet Co. v. Hollaway, 141 Tenn. 679, 214 S. W. 817 (1919) discussed by Corbin in (1920) 29 YALE L. J. 441.

13. See the standard form of an application for a life insurance policy, reprinted in PAtTerson, Cases AND OtHer Materials on THE LAW OF Insurance (1932) 819; Robinson v. U. S. Benevolent Society, 132 Mich. 695 (1903). 
hesion is hardly reflected in the great texts on contracts or in the Restatement. As a matter of fact, the term "contract of adhesion" or a similar symbol has not even found general recognition in our legal vocabulary. This will not do any harm if we remain fully aware that the use of the word "contract" does not commit us to an indiscriminate extension of the ordinary contract rules to all contracts. But apparently the realization of the deepgoing antinomies in the structure of our system of contracts is too painful an experience to be permitted to rise to the full level of our consciousness. Consequently, courts have made great efforts to protect the weaker contracting party and still keep "the elementary rules" of the law of contracts intact. As a result, our common law of standardized contracts is highly contradictory and confusing, and the potentialities inherent in the common law system for coping with contracts of adhesion have not been fully developed. The law of insurance contracts furnishes excellent illustrations. Handicapped by the axiom that courts can only interpret but cannot make contracts for the parties, courts had to rely heavily on their prerogative of interpretation to protect a policy holder. To be sure many courts have shown a remarkable skill in reaching "just" decisions by construing ambiguous clauses against their author even in cases where there was no ambiguity. Still, this round about method has its disadvantages as the story of the treatment of warranties in life insurance contracts strikingly demonstrates. Courts, when protecting an innocent policy holder against the harshness of the doctrine, did not state clearly that as a matter of public policy an insurance company cannot avoid liability merely because of the falsity of a statement which has been labelled "warranty". They felt that freedom of contract prevented them from saying so. Instead they disguised as "interpretation" their efforts to change warranties into representations. ${ }^{14}$ But this makeshift solution tempted insurance companies to try the usefulness of "warranties" again and again. ${ }^{15}$

Society had thus to pay a high price in terms of uncertainty for the luxury of an apparent homogeneity in the law of contracts. Finally, the legislature had to step in. In many jurisdictions warranties have been put on the same footing with representations; in fire insurance, legislation has even prescribed the contents of the standard policy. No such need has arisen with regard to contracts for reinsurance. Here parties of equal skill and bargaining power are dealing with another.

14. Cf. Moulov v. American Life Ins. Co., 111 U. S. 335 (1884); Ehrenzweig and Kessler, Misrepresentations and False Warranty in the Illinois Insurance Code (1942) 9 U. of CHr. L. Rev. 209, 210 et seq.

15. On the shortcomings of the "interpretation" device which results in a constant struggle between draftsman of standardized contracts and courts, see Llewellyn, Book Review (1939) 52 HARv. L. REv. 702, 703. 
Although the episode of warranties, because of the intervention of legislation, belongs largely to the past, another well known controversy still lacks a satisfactory solution. Courts have been unable to agree as to who shall bear the risk of "loss without insurance" caused by an unreasonable delay on the part of an insurance company in issuing a policy of insurance for which application has been made. ${ }^{16}$ Here again the pious myth that the law of contracts is of one cloth has stood in the path of progress. The courts, because of their reliance on and preoccupation with "interpretation", were lacking experience in handling this situation.

Most courts have felt rather strongly that a recovery in contract is out of the question. According to a "thoroughly established principle of the law of contracts, within the field of which insurance largely lies", an application for insurance is a bare offer and therefore imposes no liability upon the insurance company until it is accepted. Nor does it "afford a basis for any liability by reason of delay in accepting it or the want of care in dealing with it". A decision of the Connecticut Supreme Court has summed up the arguments against an implied contract in the most persuasive form:

It is of course true that failure to act upon it may, in such a case as this, cause loss to the applicant or to those to be named beneficiaries in the policy, against which he expected to secure protection. That situation is not, however, peculiar to the insurance law; for example, one may make an offer to buy goods which he needs at a certain price, having reason to believe the price will advance, and may incur loss through the failure of the one to whom it is made to act upon the offer within a reasonable time. ${ }^{17}$

To fortify the argument we are told that an implied promise for future action would be unsupported by consideration. "No legal benefit moved from the applicant to it by reason of the offer, and any detriment which the applicant suffers is not one which was contemplated by the terms of the offer or its acceptance". This is all the more true, courts assure us. since the applicant does not agree not to seek insurance elsewhere and is at liberty to withdraw his offer any time before acceptance. ${ }^{18}$

The argument that a recovery in contract would be "contrary to the well settled principles of contract law" has influenced almost the whole of legal literature, ${ }^{19}$ particularly since applications typically contain a provision to the effect that the company shall incur no liability under the application until it has been approved by the home office and a formal

16. Prosser, supra note 4.

17. Swentusky v. Prudential Ins. Co., 116 Conn. 526, 534 (1933).

18. $I d$. at 534 .

19. Only a few decisions have spelled out a contractual or quasi-contractual liability, for instance, Columbian Nat. Life Ins. Co. v. Lemmons, 96 Okla. 228 (1923). 
policy issued and delivered. ${ }^{20}$ Besides, we are informed, the assumption of an implied promise to act promptly "ignores actuality". "If a court should hold that a contract to decide expeditiously on the proposal did exist, it is believed that, within a short time, all insurance companies doing business in that jurisdiction would incorporate in their applications stipulations expressly negativing any such promise."21

And yet, although most courts subscribe to this doctrine, the majority still allows recovery by the back door, so to speak. They regard recovery ex contractu as impossible, but at the same time allow rerecovery $e x$ delictu. The failure of an insurance company to take prompt action-according to these decisions-amounts to the breach of a general duty towards the public to act without undue delay on applications for acceptable risks. ${ }^{22}$ The courts are sure that the policy of insurance cannot be treated like any other contract. The state, by granting a franchise to the insurance company, by regulating and supervising its business, recognizes the great social importance of insurance business; it is, therefore, in the public interest that applications for acceptable risks shall not be unduly delayed. Thus the courts pay merely lip service to the dogma that the common law of contracts governs insurance contracts. With the help of the law of torts they nullify those parts of the law of contracts which in the public interest are regarded as inapplicable. Disguised as tort law the courts recognized a liability for culpa in contrahendo thus making new law with regard to the formation of insurance contracts. This approach enables them to disregard the clause in the application by means of which the company attempted to avoid liability prior to the delivery of the policy. No wonder that this line of reasoning has been sharply criticized not only for its inconsistency ${ }^{23}$ but also for undermining legal certainty and the stability of the insurance business. To impose upon an insurance company, because it acts under franchise from the state, a duty to act promptly on an application

20. Prosser, supra note 4 , at 40,41 . For an analysis of the function of the clause and the efforts of courts to protect the interests of the applicant by manipulating the symbol "delivery," see Patterson, supra note 11, at 218, 221, 222.

21. Funk, The Duty of an Insurer to Act Promptly on Applications (1927) 75 U. OF PA. L. REv. 207, 214.

22. Duffie v. Bankers' Life Ass'n, 160 Iowa 19, 139 N. W. 1087 (1913); for further cases, Prosser, supra note 4, at 41 ef seq.

23. Savage v. Prudential Life Ins. Co., 154 Miss. 89, 121 So. 487 (1929). "To hold that there is no contract, nor breach of a contract, in failing to insure this applicant, or to notify him that he was not insured, and then to hold that a tort arises, is to hold that there was created a legal duty, and to this we cannot subscribe." Id. at 489. The situation is unlike that in the early history of contract law where contractual liability was developed with the help of the action on the case. In the insurance cases contract and tort analyses represent conflicting ideologies. 
would be to open a field of legal liability the limits of which we cannot encompass, and which would go far to introduce chaos in the entire business of insurance, indeed, would almost necessarily reach out into the field of other specially chartered corporations occupying not dissimilar relations to the public, as banks, utility companies, and the like. Public interest more requires that stability of the insurance business which is necessary to guard the great body of persons who enter into relations with it for their own protection and that of those dependent upon them, than it does that certain individuals should be saved the loss which may result by adherence to established legal principles."

This line-up of arguments brings out clearly the basic issue with which the courts in the insurance cases are confronted. It is: can the unity of the law of contracts be maintained in the face of the increasing use of contracts of adhesion? The few courts which allow recovery in contract and the many which allow recovery in tort feel more or less clearly that insurance contracts are contracts of adhesion, and try to protect the weaker contracting party against the harshness of the common law and against what they think are abuses of freedom of contract. The courts denying recovery, on the other hand, cling to the belief that an application for insurance is not different from any other offer, and they are convinced that efforts to build up by trial and error a dual system of contract law must inevitably undermine the security function of all law, particularly since courts are ill equipped to decide whether and to what extent an insurance contract has compulsory features.

To be sure, the task of building up a multiple system of contract law is eminently difficult, particularly since courts are not commissions which are able to examine earefully the ramifications of the problem involved, and can see only the narrow aspect of the total problem which comes up for litigation. Equally difficult is the job of determining whether and to what extent a contract, for instance that of insurance, is a contract of adhesion. Still, the predicament to which an applicant for insurance is exposed by an unreasonable delay in handling his application is deserving of more serious consideration than the assertion that in case of unreasonable delay the applicant can withdraw his offer and apply elsewhere. The denial of liability may very well put a premium on inefficiency. It is submitted that in this respect the attitude of the courts which allow the applicant to recover as if he were insured is more realistic, provided the risk was acceptable and the insurance company, in dealing with the application, deviated from its standard pattern of behavior, on which the applicant could reasonably rely. ${ }^{25}$ There has been

24. Swentusky v. Prudential Ins. Co., 116 Conn. 526, 532 (1933).

25. Until now decisions allowing recovery in tort have been rather lax in requiring evidence that the delay in handling the application has caused "loss with- 
no evidence that the insurance business has been unable to adjust itself to the new law created by the decisions allowing recovery. This is not surprising since deviations from the standard practice in handling applications which result in "loss without insurance" are the exception. ${ }^{26}$

The idea implicit in the cases which allow recovery seems very fruitful indeed. In dealing with standardized contracts courts have to determine what the weaker contracting party could legitimately expect by way of services according to the enterpriser's "calling", and to what extent the stronger party disappointed reasonable expectations based on the typical life situation. ${ }^{27}$ It can hardly be objected that the resulting task of rewriting, if necessary, the contents of a contract of adhesion is foreign to the function of common law courts; the judge-made law in the field of constructive conditions is amply proving the opposite and refutes the contention that a contract implied in fact does not differ from an express contract except that the intention of the party is circumstantially proved. ${ }^{28}$

The task of adjusting in each individual case the common law of contracts to contracts of adhesion has to be faced squarely and not indirectly. This is possible only if courts become fully aware of their emotional attitude with regard to freedom of contract. Here lies the main obstacle to progress, particularly since courts have an understandable tendency to avoid this crucial issue by way of rationalizations. They prefer to convince themselves and the community that legal certainty and "sound principles" of contract law should not be sacrificed to dictates of justice or social desirability. Such discussions are hardly profitable.

To be sure, "case law and the feeling of justice are certainly not synonymous" $;{ }^{29}$ it is just to obey laws of which one does not approve.

out insurance." For a decision insisting that the plaintiff can recover only if he had reason to believe that a policy would be issued to him and if he were precluded to his damage from procuring other insurance, see Wallace v. Metropolitan Life Inc. Co., 212 Wis. 346,248 N. W. 435 (1933).

26. The practice of antedating insurance by using premium receipts is a step in the right direction but hardly goes far enough. The applicant, if he is protected at all against the risk of delay, is only protected if he has paid the first premium in full. He is not protected for instance if he has only made a down payment on the first premium, as illustrated by Swentusky v. Prudential Ins. Co., 116 Conn. 526, cited supra note 17. Whether and to what extent the applicant is protected depends further on the type of the premium receipt used. For a description of the various types of premium receipts used and their shortcomings, see Comment (1935) 44 Y ALE L. J. 1223.

27. Llewellyn, Review (1939) 52 Harv. L. Rev. 700, at 704. Llewellyn calls our attention to the case law on oral contracts to insure which indeed shows the ingenuity of common law courts in making contracts for the parties on the basis of the typical life situation. See, for instance, Aetna Ins. Co. of Hartford, Conn. v. Licking Valley Millings Co. (C. C. A. 6th, 1927) 19 Fed.(2d) 177; Patrerson, supra note 9 at $59 \mathrm{ff}, 64 \mathrm{ff}$.

28. Prosser, sipra note 4 , at 49.

29. M. Cohen, Positivism and the Limits of Idealism in the Law, Procendrngs of the Sixth Internationat. Congress of Philosophy (1927) 469, 470. 
But it is equally true that the rules of the common law are flexible enough to enable courts to listen to their sense of justice and to the sense of justice of the community. Just as freedom of contract gives individual contracting parties all the needed leeway for shaping the law of contract according to their needs, the elasticity of the common law, with rule and counterrule constantly competing, makes it possible for courts to follow the dictates of "social desirability". Whatever one may think about the possibility of separating the "law that is" from the "law that ought to be", this much is certain: In the development of the common law the ideal tends constantly to become the practice. And in this process the ideal of certainty has constantly to be weighed against the social desirability of change, and very often legal certainty has to be sacrificed to progress. The inconsistencies and contradictions within the legal system resulting from the uneven growth of the law and from conflicting ideologies are inevitable. ${ }^{30}$

It is not even profitable to spend "the energy of counsel, the money of clients and the time and analysis of judges" 31 in discussing the problems presented by contracts of adhesion in terms of established legal principles and to proclaim that recovery is "contrary to the well settled principles of contract law". This approach tries to create the impression tbat the rules concerning the formation of contracts are a closed and harmonious system. But this is hardly the case. The doctrine of consideration, for instance, more than any other doctrine, is in a constant process of evolution, full of contradictions and inconsistencies. ${ }^{32}$ It has responded to the belief in freedom of contract, as the pepper corn theory of consideration illustrates. It can also be used to protect a creditor against the risk of economic duress of his debtor (Foakes v. Beer)..$^{33}$ Diametrically opposed social policies have thus been defended in the name of consideration. Furthermore, the harshness of the rule of Thorne $v$. Deas, ${ }^{34}$ which

30. Still, in a time of transition like ours where the dichotomy between political freedom and economic insecurity belongs to the experience of everyday life and where the widespread feeling of economic insecurity threatens even political freedom the psychological urge to rely on the law for certainty is particularly powerful. For a penetrating psychological analysis of the emotional dilemma of modern man, see FroMM, ESCAPE FROM FREEDOM (1942).

31. Douglas, Vicarions Liability and Administration of Risk, I (1929) 38 YALE L. J. 584, 594.

32. Corbin, Recent Developments in the Law of Contracts (1937) $50 \mathrm{HARv}$ L. REv. 449, 453 et seq.

33. L. R. 9 App. Cas. 605 (1884); Sharp, Promissory Liability, II (1940) 7 U. of Car. L. Rev. 250, 253. Thus interpreted the rule in Foakes $\%$ 'Becr is not as conceptualistic as its critics contend.

34. 4 Johns. 84 (N. Y. 1809). It is difficult to believe that the efforts on the part of some courts [c.g., Comfort v. McCorkle, 149 Misc. 826, 268 N. Y. Supp. 192 (1933)] to reconcile $\$ \$ 45$ and 90 of the Restatement by limiting the application of promissory estoppel to charitable subscriptions and promises to make gifts (non-commercial cases) will be successful in the long run. 
seems to support the theory of the courts which deny liability in contract, is mitigated by a counter rule which is constantly gaining in strength and has found expression in Section 90 of the Restatement. Even the mere risk of reliance has been regarded sufficient consideration, ${ }^{35}$ a doctrine which comes in handy here to offset the argument that the applicant could have withdrawn his application and applied for insurance elsewhere. It is true that acceptance of the application can hardly be inferred from silence for an unreasonable length of time since the standard clause in the application expressly warns the applicant that the company shall incur no liability under the application until it has been approved and a formal policy has been issued and delivered. But is this clause sufficiently unequivocal to negative not only an acceptance by silence but also an implied collateral promise (as it is technically called) to take prompt action on an application for an acceptable risk ?36 More serious is the argument that the assumption of an implied promise to act promptly is unrealistic because insurance companies, once subjected to such an implied promise, would immediately negative it by express stipulation in the policy. But is this argument not begging the question? The crucial problem is not whether insurance companies would insert such a clause but whether they could do so with impunity.

Thus, technical doctrines of the law of contracts cannot possibly provide the courts with the right answers. They convince only those courts which are already convinced. For instance, which consideration doctrine the court is going to choose as the correct one depends upon its attitude with regard to freedom of contract. All the technical doctrines resorted to by the courts in the insurance cases denying liability are in the last analysis but rationalizations of the court's emotional desire to preserve freedom of contract. Even the cases which hold the insurance company liable in tort pay tribute to the dogma; otherwise it would have been unnecessary constantly to emphasize that the plaintiff is not seeking recovery in contract. The freedom of contract dogma is the real hero or villain in the drama of the inșurance cases, but it prefers to remain in the safety of the background if possible, leaving the actual fighting to consideration and to the host of other satellites-all of which is very often confusion to the audience which vaguely senses the unreality of the atmosphere.

35. For a collection and discussion of authorities see Note, Promissory Obligations Based on Past Benefits or Other Moral Obligations (1939) 7 U. oF CHI. L. REV. 124, 133 et seq.

36. The risk of reliance furnishes the needed consideration. The situation is in a way the reverse to that presented by Los Angeles Traction Co. v. Wilshire, 135 Cal. 654, 67 Pac. 1086 (1902) and similar cases envisaged by $\S 45$ of the $R E$ STATEMENT OF CONTRACTS. 
Still, the tort cases are a constant though indirect challenge to the claims of the freedom of contract dogma. They keep alive the question whether or not the "received ideas"37 on freedom of contract which form the background of the insurance cases represent a cultural lag.

The individualism of our rules of contract law, of which freedom of contract is the most powerful symbol, is closely tied up with the ethics of free enterprise capitalism and the ideals of justice of a mobile society of small enterprisers, individual merchants and independent craftsmen. This society believed that individual and cooperative action left unrestrained in family, church and market would not lessen the freedom and dignity of man but would secure the highest possible social justice. It was firmly convinced of a natural law according to which the individual serving his own interest was also serving the interest of the community. Profits can be earned only by supplying consumable commodities. Freedom of competition will prevent profits from rising unduly. The play of the market if left to itself must therefore maximize net satisfactions. Justice within this framework has a very definite meaning. It means freedom of property and of contract, of profit making and of trade. ${ }^{38}$ Freedom of contract thus receives its moral justification. The "prestabilized harmony" of a social system based on freedom of enterprise and perfect competition sees to it that the "private autonomy" of contracting parties will be kept within bounds and will work out to the benefit of the whole.

With the decline of the free enterprise system due to the innate trend of competitive capitalism towards monopoly, the meaning of contract has changed radically. Society, when granting freedom of contract, does not guarantee that all members of the community will be able to make use of it to the same extent. On the contrary, the law, by protecting the unequal distribution of property, does nothing to prevent freedom of contract from becoming a one-sided privilege. Society, by proclaiming freedom of contract, guarantees that it will not interfere with the exercise of power by contract. Freedom of contract enables enterprisers to legislate by contract and, what is even more important, to legislate in a substantially authoritarian manner without using the appearance of authoritarian forms. Standard contracts in particular could thus become effective instruments in the hands of powerful industrial and commercial overlords enabling them to impose a new feudal order of their own making upon a vast host of vassals. ${ }^{39}$ This spectacle is all the more fascinating since not more than a hundred years ago contract ideology had been success-

37. Pound, The New Feudalism (1930) 16 A. B. A. J. 553, 554.

38. See Hamilton, Competition, 2 ENcyc. Soc. Scr. 141, 142.

39. See Note, "Mutuality" in Exclusive Sales Agency Agreenents (1931) 31 Columbia law Rev. 830 et seq. 
fully used to break down the last vestiges of a patriarchal and benevolent feudal order in the field of master and servant (Priestley v. Fozeler). Thus the return back from contract to status which we experience today was greatly facilitated by the fact that the belief in freedom of contract has remained one of the firmest axioms in the whole fabric of the social philosophy of our culture.

The role played by contract in the destruction of the institutional framework of capitalistic society is constantly obscured to the lawyer by the still prevailing philosophy of law which neglects to treat contract as the most important source of law. According to conventional theory contract is only a convenient label for a number of "operative facts" which have the consequences intended by the parties if the law so ordains. ${ }^{40}$ In this respect the great philosophers of natural law thought quite differently: society, in proclaiming freedom of contract-according to their teaching-has delegated to individual citizens a piece of sovereignty which enables them to participate constantly in the law making process. Freedom of contract means that the state has no monopoly in the creation of law. The consent of contracting parties creates law also. The lawmaking process is decentralized. As a result, law is not an order imposed by the state from above upon its citizens; it is rather an order created from below. This was a realistic insight.11 Unwarranted, however, was the optimistic belief that capitalism meant a permanent advance over the preceding social system, feudalism, because of the fact that contract and not status had become the chief means of social integration. Nor can we subscribe to the thesis of natural law philosophers that the progress in any society towards freedom is to be measured by the extent to which all political relations can be reduced to contract, "the perfect form of obligation".

In the happy days of free enterprise capitalism the belief that contracting is law making had largely emotional importance. Law making by contract was no threat to the harmony of the democratic system. On the contray it reaffirmed it. The courts, therefore, representing the community as a whole, could remain neutral in the name of freedom of contract. The deterioration of the social order into the pluralistic society of our days with its powerful pressure groups was needed to make the wisdom of the contract theory of the natural law philosophers meaningful to us. The prevailing dogma, on the other hand, insisting that contract is only a set of operative facts, helps to preserve the illusion that the "law" will protect the public against any abuse of freedom of contract.

40. 1 Williston, Contracts (rev. ed. 1936) $\$ 1$; Restatement, Contracts (1932) $\S 1$; Pound, Contract, 2 ENCYC. Soc. SCI. 323 .

41. See M. Cohen, The Basis of Contract (1933) 46 HARv. L. REv. 553, 585. 
This will not be the case so long as we fail to realize that freedom of contract must mean different things for different types of contracts. Its meaning must change with the social importance of the type of contract and with the degree of monopoly enjoyed by the author of the standardized contract. 